\title{
"Refugee Voices," New Social Media and Politics of Representation: Young Congolese in the Diaspora and Beyond
}

\author{
MARIE GODIN AND GIORGIA DONÁ
}

\begin{abstract}
This article examines the role of new social media in the articulation and representation of the refugee and diasporic "voice." The article problematizes the individualist, de-politicized, de-contextualized, and aestheticized representation of refugee/diasporic voices. It argues that new social media enable refugees and diaspora members to exercise agency in managing the creation, production, and dissemination of their voices and to engage in hybrid (on- and offline) activism. These new territories for self-representation challenge our conventional understanding of refugee/diaspora voices. The article is based on research with young Congolese living in the diaspora, and it describes the Geno-cost project created by the Congolese Action Youth Platform (CAYP) and JJ Bola's spoken-word piece, "Refuge." The first shows agency in the creation of analytical and activist voices that promote counter-hegemonic narratives of violence in the eastern Democratic Republic of Congo, while the second is an example of aesthetic expressions performed online and offline that reveal agency through authorship and ownership of one's voice. The examples highlight the role that new social media play in challenging mainstream politics of representation of refugee/diaspora voices.
\end{abstract}

\section{Résumé}

Cet article étudie le rôle des nouveaux médias sociaux dans la politique de la représentation de la «voix» des réfugiés et de la diaspora. Il propose une problématisation des approches trop souvent dépoliticisées, uniformisées et individualisées à la représentation des "voix des réfugiés et de la diaspora». Il soutient que les nouveaux médias sociaux permettent aux réfugies d'exercer leur propre volonté d'agir en gérant la création, la production et la dissémination de récits alternatifs et en s'engageant dans un militantisme hybride (en ligne ainsi que hors ligne). Ces nouveaux lieux d'auto-représentation mettent en question nos conceptions conventionnelles des voix des réfugiés et de la diaspora. En se basant sur la recherche parmi de jeunes Congolais faisant partie de la diaspora au Royaume-Uni, l'article décrit le projet geno-cost développé par le Congolese Action Youth Platform (CAYP), ainsi que la création poétique orale intitulée "Refuge» de JJ Bola. Le premier exemple étudie l'exercice de la volonté d'agir qui se manifeste dans le développement de voix analytiques et militantes qui appuient des récits anti-hégémoniques concernant les causes et les solutions du conflit prolongé en République démocratique du Congo, alors que le deuxième exemple représente une instance d'expression politique et esthétique performée en ligne ainsi que hors ligne qui démontre la volonté d'agir par l'entremise de la création et la possession de sa propre voix. Effectivement, ces exemples soulignent le rôle que jouent les nouveaux médias sociaux pour contrer les politiques conventionnelles de représentation en matière de voix des réfugiés et de ceux qui font partie de la diaspora. 


\section{Introduction}

This article argues that the use of new social media challenges mainstream constructions of "refugee voices" in two ways: first, by challenging existing power relations among refugees/diaspora members and other social actors such as researchers, representatives of humanitarian agencies, and journalists; and second, by enabling refugee and diasporic groups to challenge the concept of "refugee voices" by re-politicizing, heterogenizing, and adding a collective dimension to the term. The accessibility of new social media promotes refugee agency in managing the creation, production, and dissemination of a multiplicity of "situated refugee voices" while challenging some of its misconceptions. In the first section of the article we problematize the concept of "refugee voices." The second section describes two projects that highlight new ways of representing activist "voices" within the Congolese diaspora youth. The last section discusses the ways in which projects that use new social media challenge the conventional politics of representation of "refugee voices."

\section{Problematizing "Refugee Voices"}

The introduction of the term refugee voices or voice into the discussion of migration and refugees was instrumental in making explicit the contribution of refugee diasporas to the production of knowledge and action. In the first issue of the Journal of Refugee Studies (JRS) (1988), the editor Roger Zetter wrote, "JRS will actively encourage publication of material in this genre, especially by refugees. We wish to give expression to their voices as much as to their existence as research data, and to their stories as much as their abstraction as cases."2 Following this statement, "Refugee Voice Section" appeared in the $J R S^{3}$ as well as in other dedicated edited collections on refugees. ${ }^{4}$ Under the umbrella term, refugees have come to occupy centre stage in relation to other social actors. Their stories, which might otherwise have remained unheard and been excluded from state/agency-centred representations, are made audible. Forced migrants become narrating subjects who challenge portrayals of refugees as passive, vulnerable, needy victims or threatening outsiders ${ }^{5}$ and whose accounts refer to personal, lived, and first-hand experiences of persecution, displacement, and exile. ${ }^{6}$

Subsequently, "refugee voices" have become more audible in the aesthetic/cultural production of exile, migration, and diasporic life.7 In order to avoid what is called the "expert testimony" mode ${ }^{8}$ to represent the conditions under which refugees live, some organizations have opted to use testimonies, life stories, narratives, and other forms created by refugees themselves to advocate on their behalf. Yet, despite a will to listen, these voices still speak, as Rajaram ${ }^{9}$ says, within boundaries that are ideologically framed and rely on topdown analyses of need assessment for refugees. This approach reproduces discursive Western frames based on trauma and pathologization and gives credibility to humanitarian actors in speaking for refugees. ${ }^{10}$ In spite of the inclusive aims of the "refugee voices" project, there are limitations and contradictions in its application. These potential limitations, which are examined in the next section, are interrelated. Our research on new social media and the politics of representation of "refugee voices" allows us to explore three potential shortcomings in current uses: first, it is a form of de-politicization; second, it tends toward homogenized representation; and finally, as a process it is de-collectivized.

\section{"Refugee Voices" as "De-politicized Voices"}

There is a political dimension to the refugee experience whose significance can be lost in personal accounts framed by social actors such as academics and representatives of humanitarian organizations. Refugees' political lives often disappear into the background, and their "voices" tend to become apolitical. ${ }^{11}$ The term refugee voices becomes synonymous with the personal and human side of the story, marginalizing individual or collective self-representation. Abstracting displaced people from specific political, historical, and cultural milieus may ultimately lead to what Malkki calls the silencing of refugees. ${ }^{12}$ While refugees flee their country as political subjects, during their journey they appear to lose political agency to become, upon arrival in host countries, the objects of migration and asylum policies, the beneficiaries of assistance, or individuals with traumatic stories. This de-politicization regularly persists after they have settled in their host society.

\section{"Refugee Voices" as a Being Homogenized as "One Voice"}

The term refugee voices can lead to a homogenized representation of the refugee experience. This is visible in the idea of the refugee journey or cycle or the emphasis on the human and psychological dimension. The personal experience is often represented through the idea of phases or cycles classically described in terms of pre-flight, flight, and post-flight (resettlement or return) ${ }^{13}$ or the refugee cycle. ${ }^{14}$ The phases are divided, and the links across them are being reimagined; the traumatic dimension of their experience is emphasized. In this process, different experiences are transformed into one universal refugee voice that summarizes the human/psychological trajectory from violence to safety. Refugees' narratives tend to convey similar experiences of loss, trauma, vulnerability, resilience, and ultimately some form of adaptation. ${ }^{15}$ The qualitative singularities of multiple "refugee/diasporic voices" become a homogenous narrative within which context and diversity become secondary, rarely appearing in humanitarian, academic, or media discourses. 
"Refugee Voices" and the Exclusion of the Collective Dimension

The de-politicization and individualization of voices leave less room for collective histories or situated belongings. Telling only the "human" side of the story can lead to collective disempowerment, by which the socio-cultural contexts are marginalized and the collective experience is made secondary. ${ }^{16}$ The experience of violence and persecution is a collective and situated one, yet through their journey the personal prevails over the collective and the situated positionality. The focus on individual experience forces the refugee to deny the collective dimension of persecution, leading to a form of unrootedness. Such normative discourses create empathy and a sense of a better understanding of the refugee/diasporic experience, but they also create a distance between a hypothetical "us" versus "them." The connection between the two is often annihilated, and that leads to an absence of critical reflection by the international humanitarian regime, ${ }^{17}$ and to a denial of the global ethical responsibility concerning the root causes of migration.

In this article, based on our research with young Congolese in the United Kingdom, we use two examples of refugee/ diasporic voices that use social media and challenge de-politicized, homogenized, and individualistic representations while adding layers of complexity within this landscape of the politics of representation.

\section{New Mediated Political Territories for Self- Representation: Forced Migration, "Refugee Voices," and New Social Media}

As highlighted by Horst in her pioneering article on the value of electronic media for research amongst refugee diasporas, "Far from being 'virtual,' computer-mediated communication is yet another means of social contact between people at a distance from each other." 18 Since then, a range of studies have provided a substantial analysis of information and communications technology (ICT) refugee literacy through which refugees can perform their agency despite restrictive asylum policies. These narratives ${ }^{19}$ are therefore in stark contrast with prevailing clichés of refugees as needy, vulnerable, passive, and victims. Doná makes the point that in protracted refugee situations, forced migrants living in prolonged displacement create a virtual form of homemaking, linking past with future "Homes."2o

Other studies reflect on how social media can be a way for refugees to distance themselves from the refugee label and its negative connotations. In this respect, Witteborn shows how "technologically mediated sociality" ${ }^{21}$ can either enable refugees to become invisible (as deficient categories) and assert themselves in the virtual as well as embodied realm through co-presence and self-representation, or can also be used to become visible as a political force. ${ }^{22}$ The "refugee" label is then redefined by refugees and becomes a discursive force for political mobilization both online and offline. In contrast to the idea of "being a refugee" (a more static and essentialist approach), Witteborn introduces a more dynamic approach through the concept of becoming: "a process through which people shift between different moments and ways of being and relating while responding to historical, sociopolitical and economic realities, and moving towards new ways of experiencing and acting in the world."23

New ICTs promote the articulation of diasporic and refugee voices in transnational and trans-generational spaces that enable the creation of narratives that are both lived and alive, and promote hybrid activism in virtual and nonvirtual spaces. ${ }^{24}$ The Internet brings people into contact in a public agora, to voice their concerns and share their hopes. As Bernal argues, "People's control of this public agora is perhaps the most fundamental political issue raised by the development of the internet." 25 Many authors have argued that second-generation migrants are less likely to engage with their country of origin with the same intensity and frequency as their parents. ${ }^{26}$ But as Levitt points out there are no clear-cut divisions between the home country and the host country, between the first and the second generation, all of which are integrated within an interconnected social experience. ${ }^{27}$ There is a growing literature on the political activism of the $1.5 /$ second generation that describes new ways of engaging with the politics of representation. ${ }^{28}$ The examples below show that a plurality of identities can become visible through the use of social media establishing connections beyond the too-often ascribed identity categories either as refugees or diaspora actors.

\section{Methodology}

This article draws evidence from our ethnographic research with young Congolese in the United Kingdom. First, we examine the Geno-cost project ${ }^{29}$ undertaken by the Congolese Action Youth Platform (CAYP) ${ }^{30}$ to denounce the ongoing narrative of denial of the genocide in eastern Democratic Republic of Congo (DRC). Geno-cost is a project that is present both online (Twitter, Facebook, and a blog) and offline. Ethnographic work was undertaken between October 2012 and August 2015 with CAYPV's active members. One of the co-authors participated in CAYP's weekly Skype meetings where projects were discussed and connections with young Congolese living both in DRC (city of Goma, eastern DRC) and Europe (e.g., Belgium) were maintained. Additionally, physical meetings took place regularly in London. Relying on Boellstorff's definition of digital anthropology as a technique to study "the relation between the 
virtual (the online) and the actual (the physical or offline)," we explored this project both in its virtual manifestations and in its relations to the actual. ${ }^{31}$ Second, we examine the spoken word piece "Refuge" by JJ Bola, a young British Congolese born in Kinshasa and raised in London. Bola is a writer, poet, spoken word artist, social commentator, speaker, and educator. "Refuge" has appeared on social media platforms such as YouTube and Facebook, and in his blog. ${ }^{32}$ Two in-depth interviews with Bola were conducted in London between March and December 2014.

To help us reconsider the power relations between the researcher and the youth, we rely mainly on feminist methodology literature, which strives for more reciprocal relationships rethinking approaches to "subalternity, voice, authorship, and representation." 33 Young activists in the Congolese diaspora, whom one of the authors interviewed in the framework of her $\mathrm{PhD}$ dissertation, can be identified as activist-researchers, whereas she, being foremost a researcher, has become a research-activist within CAYP. Both researchers initiated (as much as possible) a transversal political dialogue. Via the interplay between acts of rooting and shifting-as defined in transversal politics ${ }^{34}$-we have tried to place ourselves in a position to hear "multiple voices of knowledges" and discuss them. In essence, the research aims to be useful in working towards their goals of social justice and social change. Using feminist research practices, we have tried to achieve a process of "research with" or "for" rather than "on." 35 To avoid misrepresenting their voices, we have, as promoted by Bassel, been "shifting from speaking to listening." 36 While we are aware that we are still part of the "old system," our standpoint is different. With social media, there is scope for much greater open access, critical discussions, and more equal relationships allowing for conventional boundaries to be broken. The "subjects" have more resources to challenge researchers, who might misrepresent them, pushing them to be more accountable. The research therefore takes place within a broader environment of "political listening"37 allowing young people to challenge knowledge hierarchies as well as hierarchies of credibility..$^{8}$

The virtual aesthetic narratives of the Geno-cost project and the "Refugee" poem show the will of second-generation Congolese in the United Kingdom to counter hegemonic narratives of the DRC conflict and its root causes and solutions while challenging the widespread image of the refugee as "bogus" through both virtual and non-virtual aesthetic representation, hybrid activism, and live narratives.

\section{A New Generation of Young Congolese Activists in the United Kingdom}

Young refugees and members of diasporas are part of mixed migratory flows in which forced and voluntary motives cannot be separated. Young people make transnational connections that are often based on their identification with their country or their families. The global increase in asylum seekers and refugees since the 1990s has made the criterion of dispersion (forced or otherwise) widely understood as constitutive of diaspora. ${ }^{39}$ However the usual concept of diaspora de-emphasizes the forced component of migration. Therefore, the terms refugee voices and diaspora voices can overlap, as they do in our case study. As discussed by Garbin and Godin, ${ }^{40}$ a Congolese diaspora first emerged in Europe during the 1960 s and early 1970 s in Belgium, the former colonial power. The majority were students and senior civil servants and elites of the Mobutu regime who were then migrating temporarily basis. In the aftermath of independence, many settled in Belgium as the result of the political and economic turmoil in the Congo. In the late 1980 s and especially in the early 1990s, with the deterioration of socio-economic conditions in the Congo and more restrictive asylum and migration policies in France and Belgium, new destinations emerged such as South Africa, Nigeria, France, Canada, and the United Kingdom. In the United Kingdom, the Congolese represent the biggest group among the new francophone African diasporas. ${ }^{41}$

The collective mobilization of young Congolese in London can be traced to the autumn and winter of 2011-12 when a tense electoral campaign in the home country led to the contested re-election of Joseph Kabila as president of the DRC. ${ }^{42}$ For many Congolese youths in the United Kingdom, the 2011 presidential and parliamentary elections in the DRC ( 28 November) were the triggers that motivated them to raise their own voices. Because there was no representational space for their concerns and political analyses in the diaspora and in mainstream institutions in the host society, young Congolese activists in the United Kingdom enacted a significant shift in representing their political concerns. As one young Congolese activist from CAYP explained during an interview, "We were outraged at the fact that we were protesting for three months in central London, Oxford Circus, in Regent Street and even outside the door of the British Broadcasting Corporation, the $\mathrm{BBC}$, and yet there was almost no coverage in the mainstream news. And the couple of articles were focusing ... on misrepresenting or demonizing the protests by telling that they were causing a lot of disruptions to the public order, rather than stating the outcry that was going on." 43

This account explains why young Congolese have used social media as the main transmitters of their political voice. As CAYP's spokesperson pointed out during a public meeting, they decided to "replace the ввс." 44 Their agency is exercised in the new social media, which are more effective tools for conveying their concerns, raising awareness, and expressing 
their voices. As there was no representational space for their concerns and political analysis in mainstream institutions of the host society, and within the diasporic political mediaspace dominated by more radical activists such as Les Combattants (The fighters), who are mainly male activists of the first generation, ${ }^{45}$ young Congolese in the United Kingdom have decided to take greater ownership of their voice, the spaces in which it is represented, and the modes of representation. ${ }^{46}$ One of their campaigns is the Geno-cost project, which suggests alternatives and counter-narratives through both virtual and non-virtual forms of political representations that promote young people's agency.

\section{The Geno-cost Project}

The Geno-cost project is the result of young Congolese people's research, revisiting dominant historic representations of the conflict in eastern DRC, and generating their own counter-hegemonic historic narrative of events. The word Geno-cost combines the term geno for genocide and cost. The term genocide highlights the systematic killing of the population of the DRC and refers to the official definition of the term adopted by the United Nations General Assembly. 47 To mark the specificity of several genocides that took place in the DRC, CAYP wanted to establish a direct link between the killing of people and the plundering of natural resources. The central platform of the project is an event that represents a commemoration and remembrance of all the genocides in the DRC during and since colonialism, but also the one that is still happening. The "cost" of the Geno-cost project highlights the economic roots of the conflicts, as CAYP's spokesperson explained: "Congolese people are not dying because they are Congolese, but because of a predator industry that only cares about money, not people." 48 This statement expresses a collective political voice that in the mainstream conceptualization of refugee/diasporic voices is often marginalized or missing. Instead of privileging the formation of individual agentic voices, young Congolese in the diaspora are producing new forms of collective and intersubjective agentic voices through social media. The Geno-cost project is a commemorative day that has taken place every 2 August since 2013. As one active member of the platform explained during one of these events,

When we started doing our research, we realized that no one spoke of the dead in Congo, the six million people who have died in the heart of Africa, the deadliest conflict since World War II, and it does not make the headlines like Syria, like Afghanistan and Libya ... and this conflict has lasted for more than twenty years. So we decided that we had to do something ... What was sad is when we did our research, we came across a date that we, the Congolese, did not know about; it is the date of 2 August 1998, the second war of aggression in the Congo 49 ... This is a date we do not know about as a community, and if we, the Congolese people, don't start to commemorate this date, it is a date that will be erased..$^{\circ}$

CAYP's initiative is directed towards the Congolese community and therefore aims at internal rather than external awareness. It is defined by CAYP's activists as a political duty enacted against a habit (especially of the elders) that has been characterized for too long by an attitude of dependency by the Congolese people on the West and a reliance on others to define them.

As highlighted by Bernal, the use of new social media allows diasporic communities to transform the ways in which the national politics of representation of individual and group histories are conducted and understood. ${ }^{51}$ One aim of the Geno-cost annual event is for young Congolese activists to promote "counter-hegemonic positive voices." To do so, CAYP members bring in not only their own perspectives, but those of young people still living in the DRC. For instance, during the second Memorial Day in 2014, a short documentary was screened: Resilience: Tales from Goma, ${ }^{52}$ produced with the support of CAYP members in Goma. Using a weekly Skype meeting, members based in Goma, London, and Brussels developed the synopsis of the documentary, which shows another side of the conflict-torn Congolese city of Goma. It portrays the work and hopes of the unsung heroes who overcame multiple challenges and obstacles to bring change and hope to the Congolese people. Resilience is the main message, defined in the documentary as "the power or ability to return to the original form, position, etc., after being bent, compressed, or stretched; elasticity-the ability to recover readily from illness, depression, adversity, or the like; buoyancy." Therefore, the project aims to amplify the voices of local people who are willing to make a change.

Resilience has been used to show that in Congolese diaspora politics the ways of being "political" and relating to the homeland are different from those of first-generation activists. First-generation political activism (as incarnated by Les Combattants) is often based on challenging those in power back home. This is done mainly through marches and petitions and can therefore be characterized as dominant diaspora politics. Showing real life for activists is also a way for young people in the diaspora to relate to political matters locally. In the literature, the 1.5 generation is often seen as a bridge between the first generation (their parents) and the host society. Here the 1.5 generation is acting as a bridge between the second generation (those who were either born in the United Kingdom or who came at an early age) who have lost contact with their "homeland" and the young 
generation back home. Through social media, a physical reconnection between the youth in the United Kingdom and Europe and the youth in the DRC can bring positive change based in local realities. In doing so, these new ways of politically representing their home country can challenge representations of the DRC, which is often portrayed in mainstream media as the "rape capital of the world" 53 or "the worst place on earth to be a woman." 54

Through the Geno-cost virtual campaign, Congolese groups and individuals around the world can support and get involved in the commemoration, online and offline. Having developed graphics for Geno-cost commemoration day, CAY P has adopted a copyleft ${ }^{55}$ strategy to get Congolese communities around the world-online and offline, in the diaspora and back home-to endorse their political project and organize their own commemorations. For instance, during the event in 2015, on several Facebook profiles, messages called for people to share via Facebook or Twitter a virtual candle as a mourning sign. As illustrated through the Twitter account of the Geno-cost project on 2 August 2015, the purpose was to remember those who died with either a real or a virtual candle that represented seventeen years of resistance, seventeen years of bravery, and seventeen years that the Congolese people will not forget (\#genocost, \#Congo).

In this way young Congolese participate in politics online by creating new territories in which the local, national, transnational, diasporic, and virtual intersect and overlap. Going online helps them gain confidence in expressing their voices and take authorship of their own research. By involving Congolese experts (academics, activists, community leaders) during the commemorative event and by emphasizing their message to a wider community online before, during, and after, they reclaim the value of the expertise of their own community, reframing the position of who is authorized to speak for whom. As one member of CAYP told the audience during the first commemoration day, "Today, it is true that Congolese people are not being told what is actually going on in Congo. Now it is time for us to actually say what we believe is going on in Congo. We are no longer in the nineteenth century. We have academics, we have historians, we have doctors and citizens, and we call ourselves 'independent.' So if we are independent we must be able to say what our history is." 56

One striking moment in the commemoration event takes place at the end, when six candles are lit one by one by members of the Congolese community (from young people to community leaders, including both men and women, representing a large spectrum of political voices within the diasporic political field). These six candles represent six prayers: to celebrate the memory of all the people Congo has lost to conflicts; for all six million lost in the ongoing conflict; for all child orphans who have lost their homes; for all victims of sexual violence; for all who have been displaced from their land; and finally, for the resistance of the Congolese people and hope for a better future. ${ }^{57}$ In doing so, the dynamics of the politics of representation are changed. Young Congolese activists in the United Kingdom and back home are working together via social media and include in their advocacy work a plurality of voices here (in the diasporic political field) but also there (back home).

One last tweet about the 2015 commemoration specifically targeted the audience online, making Geno-cost a global virtual event: "Also, to all those who shared the candle of hope in solidarity with the people of \#Congo \#DRC, thank you for making \#genocost global." 58

Young Congolese people in the diaspora recognize that it should be the state's responsibility to remember and commemorate past and ongoing violence in the DRC, and they are critical of its failure to do so. As a young Congolese activist from CAYP stated during a discussion, "Genocost will help us even pass laws back home to safeguard lives."59 The Geno-cost project aims to become a virtual war memorial of grassroots heroes. Through the use of the Internet and new social media, this young generation is creating symbolic resources to gain political support, first within the community and then in global civil society. They are writing a new national and collective history. In contrast to Rwanda, where the state, as argued by Turner, ${ }^{60}$ has been "staging" its diaspora to create a new Rwanda of national unity and reconciliation-an approach that can be characterized as "politics from above"-the Geno-cost project represents an instance of "politics from below" in which CAYP members exercise their agency and write and disseminate their own version of national history that could eventually be brought back home and re-territorialized. "Voices from above" (which include the ones from the international community, governmental representatives here and back home, Western media, etc.) are challenged through the creation, production, and dissemination of "voices from below." By using the Internet (but not only) to mark 2 August as a Congolese Genocide Remembrance Day, new forms of exilic and diasporic voices emerge that, as Bernal states, challenge conventional relationships between the state and its citizens. ${ }^{61}$ In this way, the hierarchical order is being contested between official and unofficial representations, public and private, and authorized and unauthorized voices in the refugee diaspora, back home but also beyond.

\section{The Spoken Word Poem "Refuge" by JJ Bola}

At the age of six JJ Bola arrived in London from the DRC (then Zaïre) with his family in 1992 as a refugee. As he said 
in an interview, ${ }^{62}$ he and his family experienced refugee status for almost fifteen years, obtaining British citizenship in 2007. In forced migration studies, the refugee voice of somebody like JJ Bola is usually represented through firsthand personal accounts, meaning-making, and adaptation. While some of these elements are present in JJ Bola's poem "Refuge," the direct articulation of his voice shows greater complexity, dynamism, connections, and nuances, thus challenging conventional representations of a de-politicized, homogenized, and individualized refugee voice.

"Refuge" was first performed on February 9 2014, for the burgeoning spoken word and poetry platform called Word on the Curb, ${ }^{63}$ a new social media channel using spoken word and poetry to keep people in touch with news and current affairs. It is important to note that even if spoken word poetry can be read, to get the full meaning of this piece of art the author needs to perform it. The full experience requires a multi-sensory reception of the work. This spoken work performance has since been posted on social media such as Facebook and Twitter by JJ Bola himself and shared by many of his friends and followers. The use of social media challenges the frame through which refugee voices are often represented and disseminated by intermediaries like academics and non-governmental and activist organizations.

JJ Bola's poetry is a form of literary activism promoting refugee voices and rights. As he explained to us, when he recites his poems, stereotypes and stigma against refugees are more easily dissipated as people start to listen to real voices. JJ Bola has also chosen to use social media as a "virtual speakers' corner"64 to positively influence the current refugee debate. As he mentioned, it is often easier to raise awareness online than doing it in real life, because new connections are being suggested (via powerful algorithms on whom to follow) with people who are potentially interested in the topic and who are willing to learn more about it. His message can then be spread a priori through more empathic social media such as in using specific hashtags (\#refugee, \#refugeevoice, and \#refugeeswelcome), allowing people who might not be in his circles of social relationships to learn more about his political voice.

For JJ Bola, the significance of his refugee identity emerged over time, shaped by what happened in the country of origin but also by the uncertain legal position of his family trapped in the asylum system. ${ }^{65}$ On the YouTube video, JJ Bola performs his poem on the Millennium Bridge in London, a place that stands as a metaphor for the connection between London and home (DRC), the bridge as a metaphor that stresses the continuity between "monsters" here and there, showing that the experience of being uprooted does not stop with the fleeing.
My father would speak of home. Reaching. Speaking of familiar faces. Girl next door who would eventually grow up to be my mother. The fruit seller at the market. The lonely man at the top of the road who nobody spoke to. And our house at the bottom of the street lit up by a single flickering lamp where beyond was only darkness. There we would sit and tell stories of monsters that lurked and came only at night to catch the children who sat and listened to stories of monsters that lurked. This is how they lived ... We came here to find refuge. They called us refugees so we hid ourselves in their language until we sounded just like them. Changed the way we dressed to look just like them. Made this our home until we lived just like them and began to speak of familiar faces. girl next door who would grow up to be a mother. The fruit seller at the market. The lonely man at the top of the road who nobody spoke to ... There we would sit and watch police that lurked and came only at night to arrest the youths who sat and watched police that lurked and came only at night. This is how we lived. ${ }^{66}$

The poem reflects JJ Bola's refugee experience and aims to situate the refugee ordeal in context (from the country of origin to the destination country), but it goes beyond his individual trajectory. As he tweeted in March 2015, "Being a refugee transcends class, race, gender, religion, faith, education etc. the experience stems from a trauma few know." This statement echoes what he explained to us in an interview: "What I think is unique about the refugee experience is that it challenges race, class, or even gender ... like among my peers, Afro-Caribbeans or black, I would still kind of [have the] feeling that I was being 'the refugee' and there were other friends ... who were not necessarily the same ethnic group but they could understand me because of their refugee background ... it is going beyond your own community, beyond the language of borders, it is your experience, little things." 67

However, here JJ Bola is also challenging essentialist representations of refugee identity. His aim is not to reify the refugee experience, ${ }^{68}$ which, as pointed out by Mal$\mathrm{kki}$, tends "to fix and make permanent something 'essential' about these processes and to do so by personalizing them." ${ }^{\circ}$ Through his poem, JJ Bola wants to point out that the experience of "becoming a refugee" is transcendent and goes beyond race, class, gender, religion, and any other fact; we could all be effected by it. His approach to the experience of becoming a refugee is "not to fix or make it permanent rather, it's to take a moment, and add it to the many moments that have existed previously and how the refugee experience is tied in to all of the experience of humanity."7o In line with Witterborn's concept of becoming introduced, through which people shift between different moments, in December 2014 he tweeted, "I'm a Congolese, African, 
refugee migrant, working-class boy from inner city London." Proud of his multiple social heritages, he is juggling multiple, sometimes conflicting, social identities that are paramount when looking at his poetry and political voice.

Similarly, besides his literary refugee activism, JJ Bola is concomitantly engaged in diaspora activism. As a member of CAYP, he performs his poetry at events such as the Genocost commemoration discussed earlier. On August 2, 2015, he performed the poem "tell them (they have names)":

And when they turn the bodies over

to count the number of closed eyes. And they tell you 80o,ooo:

you say no. That was my uncle. He wore bright coloured shirts and pointy shoes.

2 million: you say no. That was my aunty.

her laughter could sweep you up like

the wind to leaves on the ground.

6 million: you say no. That was my mother. ${ }^{71}$

As he tweeted the day of the event, "It should not take violent images and guilt for us to feel each other's humanity. Not for Congo, not for West Papua, Syria etc. Our human ity should not have to be evoked or provoked for us to feel another's suffering. We have been desensitized, particularly to dead black bodies; African bodies."72 This statement shows that his political engagement often goes beyond the strictly Congolese diasporic political sphere and operates across several scales, from local to global. Through his poetics of advocacy, JJ Bola is trying to raise global social awareness of global injustices and of the role that every one of us can play in not staying silent. In doing so, he is transcending traditional identity boundaries as well as voices. This capacity for juggling with a plurality of political voices and the possibility of making connections is being facilitated through social media. On 4 September 2015, JJ Bola tweeted an image of his full poem "tell them (they have names)," adding, "This is for Aylan Kurdi, who we know and for those whose names we do not know." In doing so, he shows transversality of political identities and political voices and invites everyone to do the same, encompassing difference by equality. ${ }^{73}$

On the video in which he performs the poem "Refuge," a crowd of people cross the bridge without noticing him. With this visual setting, JJ Bola wants to normalize the refugee experience that could happen to anyone, regardless of place of origin, age, sex, religion, or political opinion. $\mathrm{He}$ wants to get away from stereotypical representations of the refugee experience and to show that it is a global issue, not a personal choice. Through this spoken word piece, he aims to reverse the "humanity" of the "refugee voice" because he does not want to display sympathy or pity for the "victim" but rather solidarity based on equality, on the grounds that anybody could become a refugee, because political contexts can change anywhere: "Being a refugee is not something that you choose to become and is not based on merit or talent. It is the result of unfortunate circumstances that can affect anyone, anywhere."74 In doing so, he goes against victimization as the main meaning of the refugee experience and avoids the risk of internalizing the political representation of victimhood. He also wants to point out the need for the wider responsibility-sharing of refugee flows, not only on behalf of states but also of every individual who should always remember that he or she could become a refugee. The message of this spoken word piece is being amplified through sites like YouTube and other social media platforms, and aims to help the audience understand the connections and simultaneity of the global and the local, the personal and the collective. In the last stanza of his poem, JJ Bola brings humanity to the fore, reminding everyone that we are all potentially refugees in search of a place that can be called "home." On that basis, solidarity should prevail when dealing with refugees: "I told them that a refugee is simply someone who is trying to make a home, so next time, before you go to sleep and kiss your families goodnight, be glad that the monsters never came for you, in their suits and ties, never came for you, in the newspapers, with the media lies, never came for you, and that you are not despised. Because deep inside the hearts of each and every one of us, we are all always reaching for a place, that we can call home."75

\section{Discussion}

This article has examined the role that new social media play in the politics of representation of "refugee voices." Throughout, the opportunities of digital media and the features of different platforms such as Twitter and Facebook have been discussed, highlighting changes that new social media are making in amplifying refugee voices.

Both case studies - the CAYP Geno-cost project and the spoken word piece "Refuge" by JJ Bola - illustrate the ways in which the refugee/diaspora experience is being "re-politicized" by social media. In the Geno-cost project, young Congolese are engaged in researching, analyzing, rewriting, and retelling their country's history of violence and the conflict over natural resources and the economic costs. CAYP also wants to go beyond the individual suffering of people, such as the forced migrant. The focus is on the power relations that have led to the protracted conflict in the DRC, not on individual suffering and personal trajectories. Diasporic agents, and in particular young people, are rewriting a social national history celebrating local voices as national heroes from the grassroots level. Social media offer the space where these grassroots stories can be shared, diffused, and known. The Geno-cost event empowers the Congolese community, 
but not the people back home, as often conceptualized in diaspora studies, through concepts such as "social remittances." 76 Rather, it shares the political voices of young Congolese people back home to empower young people in the diaspora (both young men and women), to change the negative image of their country of origin, to inform them about political problems in their country of origin, and eventually to convince them to be part of a change back home. The Geno-cost event empowers the Congolese community in re-writing history from the bottom up, by and for civilians in the diaspora and back home. By taking place both online and offline, the Geno-cost project suggests a new dialectic of mutual empowerment and collaboration based on a more equal relationship between those back home, in the diaspora and beyond. In the case of JJ Bola, his poem challenges mainstream anti-refugee discourse and puts the stress on the political experience in the home country (both at the individual and collective level), but he also re-politicizes the refugee experience in the host country by establishing connections with other marginalized groups. In so doing, he shows that refugee experiences take place within a political spectrum from the country of origin to the one of settlement. The Internet and its tools (Youtube, Twitter, and Facebook) allow information and political views to be shared directly and discussed among members in a more decentralized, unregulated, and egalitarian mode.

These two examples show the heterogenization of situated voices and experience. Young Congolese activists do not pretend to be The Voice, but they are adding their voices, highlighting a heterogeneous representation of what constitutes "refugee voices." Young activists use new social media to raise political awareness, promote diasporic social and political initiatives, and participate in youth cultures within the receiving societies. For young people, new information and communication technologies have become instrumental and symbolic tools that identify them as global citizens and members of global youth cultures. Through the Genocost project, young Congolese activists are re-politicizing their positions among other dominant discourses within and beyond the diaspora, not only as Congolese young people but as global citizens.

JJ Bola's poem shows how individuals are embedded in multiple social roles and identities that often overlap, intersect, and connect. Social media allow individual and collective social actors to go beyond universalistic politics (which are ethnocentric and exclusionary) as well as identity politics (which are essentialist). ${ }^{77} \mathrm{JJ}$ Bola's public statement at the Global Summit to End Sexual Violence in Conflict in $2014^{78}$ on DRC conflict minerals and ICTs illustrates quite well this rising possibility of engagement in transversal politics by youth who are using social media:
I am just going to echo what Dr. Mukwege ${ }^{79}$ said. He spoke about there being a grassroots movement. He spoke about there being change from the bottom up ... Each and every one of us is directly affected by it [Congo's conflict minerals and the use of the mobile phone], and it is about changing the narrative and not just relying on the government or the media to dictate whatever people are thinking, but also for us to be able to speak about our experiences, to come here and have this platform where we don't just educate, but also enlighten people about what's going on back home so that each and every one of us can feel connected to the conflict back home, and connected in a sense that, we feel empowered to be able to change something ... I think it is about us, this generation, in this technological era, for us to use that, that platform that we have, to be able to spread the narrative. ${ }^{80}$

Finally, in both projects, the re-collectivization of voices takes the form of a shared collective responsibility. In the Geno-cost project, the root causes are being addressed, and everyone's responsibility and capacity for change is highlighted. JJ Bola shows that there is a shared responsibility for addressing the root causes of any refugee situation. Through his poem, he distances himself from the ordinary process of refugee homogenization as victims only, and stresses the potential universal experience of becoming a refugee. In highlighting the fact that anyone could become a refugee, he wants to stress our shared humanity as a principle that should make us feel connected to any refugee around the world. Going online makes their perspectives visible by multiple audiences, both Congolese and non-Congolese, simultaneously.

This article contributes to ongoing discussions on "Refugee Voices" by giving a voice to a social group that is often unheard in diaspora and refugee studies: the youth. It explores the nature and character of the "situated voices" of young Congolese in the diaspora and their increasing use of ICT. Social media are not free from the tangled webs of inequitable power relations across the globe. But in creating their own channels, young Congolese are challenging global power relationships as well as diasporic power relationships at the local, national, transnational, and international levels. And in their engagement, they are also challenging the mainstream politics of the representation of refugee voices.

Marie Godin is a research officer at the International Migration Institute at the University of Oxford. The author may be contacted atmarie.godin@qeh.ox.ac.uk.

Giorgia Doná is professor of refugee studies at the School of Social Sciences, University of East London. The author may becontactedatg.dona@uel.ac.uk. 


\section{Notes}

Our warmest thanks to CAYP's active members and JJ Bola for their help at different stages of the project, as well as to Professor Dawn Chatty (Refugee Studies Centre), Refuge editors and anonymous referees for their useful comments.

1 Directly inspired by the concept of "situated knowledge" coined by Donna Haraway in "Situated Knowledges: The Science Question in Feminism and the Privilege of Partial Perspective," Feminist Studies 14, no. 3 (1988): 575-99.

2 Roger Zetter, "Refugees and Refugee Studies: a Label and an Agenda: Editorial Introduction," Journal of Refugee Studies 1 (1988): 1-6.

3 For example, Ron Baker, "Refugee Experience: Communication and Stress, Recollections of a Refugee Survivor," Journal of Refugee Studies 3, no. 1 (1990): 64-71; Mia FloresBorquez, "Refugee Voices: A Journey to Regain My Identity," Journal of Refugee Studies 8, no. 1 (1995): 95-108; Martha Kumsa Kuwee, “'No! I'm not a refugee!' The Poetics of Belonging among Young Oromos in Toronto," Journal of Refugee Studies 19, no. 2 (2006): 230-55.

4 Jennifer Langer, Crossing the Border (Nottingham: Five Leaves, 2002); Julie A. Mertus, Jasmina Tesanovic, Habiba Metikos, and Rada Boric, The Suitcase: Refugee Voices from Bosnia and Croatia (Oakland: University of California Press, 1997).

5 For example, Anette Day, “They listened to my voice’: The Refugee Communities History Project and BelongingVoices of London's Refugees," Oral History 37, no. 1 (2009): 95-106.

6 See Marita Eastmond, "Stories as Lived Experience: Narratives in Forced Migration Research," Journal of Refugee Studies 20, no. 2 (2007): 248-64; Peter E. Hopkins and Malcolm Hill, "Pre-Flight Experiences and Migration Stories: The Accounts of Unaccompanied Asylum-Seeking Children," Children's Geographies 6, no. 3 (2008): 257-68; Edward W. Said, Reflections on Exile and Other Literary and Cultural Essays (Cambridge: Granta Books, 2001).

7 Zuzanna Olszewska, "A Desolate Voice: Poetry and Identity among Young Afghans in Iran," Iranian Studies 40, no. 2 (2007): 203-24.

8 Liisa H. Malkki, "Speechless Emissaries: Refugees, Humanitarianism, and Dehistoricization," Cultural Anthropology 11, no. 3 (1996): 377-404.

9 Prem Kumar Rajaram, "Humanitarianism and Representations of the Refugee," Journal of Refugee Studies 15, no. 3 (2002): 247-64.

10 Nando Sigona, “The Politics of Refugee Voices: Representations, Narratives, and Memories," in The Oxford Handbook of Refugee and Forced Migration Studies, ed. Elena Fiddian-Qasmiyeh, Gil Loescher, Katy Long, and Nando Sigona, 369-82 (Oxford: Oxford University Press, 2014).

11 Navine Murshid, The Politics of Refugees in South Asia: Identity, Resistance, Manipulation (London: Routledge, 2013).

12 Malkki, "Speechless Emissaries."
13 Egon F. Kunz, "The Refugee in Flight: Kinetic Models and Forms of Displacement," International Migration Review 7 , no. 2 (1973): 125-46.

14 Richard Black and Koser Khalid, eds., The End of the Refugee Cycle? Refugee Repatriation and Reconstruction, vol. 4 (New York: Berghahn Books, 1999).

15 Alastair Ager, ed., Refugees: Perspectives on the Experience of Forced Migration (London: Continuum, 1999); Giorgia Doná, "Psychology and the Refugee Experience," in Psychology Serving Humanity: Applications, ed. Saths Cooper and Kopano Ratele, 2:144-68 (London: Psychology Press, Taylor and Francis Group, 2014).

16 Derek Summerfield, "A Critique of Seven Assumptions behind Psychological Trauma Programmes in WarAffected Areas," Social Science \& Medicine 48, no. 10 (1999): 1449-62; Gillian McFadyen, "The Contemporary Refugee: Persecution, Semantics and Universality," in "The 1951 Un Refugee Convention: 6o Years On," special issue of $e$-Sharp (2012): 9-35, http://www.gla.ac.uk/media/ media_234569_en.pdf.

17 Sigona, "Politics of Refugee Voices."

18 Cindy Horst, "In 'Virtual Dialogue' with the Somali Community: The Value of Electronic Media for Research amongst Refugee Diasporas," Refugee 23, no.1 (2006): 53.

19 See Linda Leung, "Taking Refuge in Technology: Communications Practices in Refugee Camps and Immigration Detention," New Issues in Refugee Research, Research Paper no. 202 (Geneva: The un Refugee Agency, Policy Development and Evaluation Service, 2011); Geff Green and Eleanor Lockley, "Communication Practices of the Karen in Sheffield: Seeking to Navigate Their Three Zones of Displacement," Asian Journal of Communication 22, no. 6 (2012): 566-83.

20 Giorgia Doná, "Making Homes in Limbo: Embodied Virtual 'Homes' in Prolonged Conditions of Displacement," Refuge 31, no. 1 (2015): 67-73.

21 "Technologically mediated sociality" refers to the way social relations are being reshaped by technology in the form of Skype calls or Facebook, for instance. See Michele Willson, "Being-Together: Thinking Through Technologically Mediated Sociality and Community," Communication and Critical/Cultural Studies 9, no. 3 (2012): 279-297, and cited by Saskia Witteborn, "Becoming (Im)Perceptible: Forced Migrants and Virtual Practice," Journal of Refugee Studies 28 (2015): 351.

22 Ibid., 352.

23 Ibid., 364 .

24 For example, Angel Adams Parham, "Diaspora, Community and Communication: Internet Use in Transnational Haiti," Global Networks 4, no. 2 (2004): 199-217.

25 Victoria Bernal, "Civil Society and Cyberspace: Reflections on Dehai, Asmarino, and Awate," Africa Today 6o, no. 2 (2013): 20-36.

26 Alba Richard and Nee Victor, Remaking the American Mainstream: Assimilation and Contemporary Immigration 
(Cambridge, MA: Harvard University Press, 2003); P. Kasinitz, J.H. Mollenkopf, and M.C. Waters, Becoming New Yorkers: Ethnographies of the New Second Generation (New York: Russel Sage, 2004).

27 Peggy Levitt, "Routes and Roots: Understanding the Lives of the Second Generation Transnationally," Journal of Ethnic and Migration Studies 35, no. 7 (2009): 1225-42.

28 Monika Hess and Benedikt Korf, "Tamil Diaspora and the Political Spaces of Second-Generation Activism in Switzerland," Global Networks 14, no. 4 (2014): 419-37; Koen Leurs, Digital Passages: Migrant Youth 2.o (Amsterdam: Amsterdam University Press, 2015).

29 More information on the project can be found on "Genocost," Facebook, https://www.facebook.com/GenoCost; on the official website, http://www.genocost.org/; or "Geno-cost," Twitter, https://twitter.com/Genocost.

30 For more information, see Congolese Action Youth Platform blog, www.congoayuk.wordpress.com.

31 Tom Boellstorff, "Rethinking Digital Anthropology," in digital anthropology, ed. Heather A. Horst and Daniel Miller, 39-6o (Oxford: Berg Publishers, 2012).

32 See "JJ Bola," Facebook, https://www.facebook.com/ jj.bola?fref=ts; http://www.jjbola.com; "JJ Bola," Twitter, https://twitter.com/JJ_Bola.

33 Amanda Lock Swarr and Richa Nagar, Critical Transnational Feminist Praxis, suny Series, Praxis: Theory in Action (New York: suny Press, 2010).

34 Nira Yuval-Davis, "Human/Women's Rights and Feminist Transversal Politics," in Transnational Feminisms: Women's Global Activism and Human Rights, ed. M.M. Ferree and A. Tripp, 275-95 (New York: New York University Press, 2006).

35 Liz Stanley and Sue Wise, Breaking Out: Feminist Consciousness and Feminist Research (London: Routledge \& Kegan Paul, 1983).

36 Leah Bassel, "Speaking and Listening: The 2011 English Riots," Sociological Research Online 18, no. 4 (2013): 12, http://www.socresonline.org.uk/18/4/12.html.

37 Susan Bickford, The Dissonance of Democracy: Listening, Conflict and Citizenship (Ithaca, NY: Cornell University Press, 1996).

38 Bassel, "Speaking and Listening."

39 Rogers Brubaker, "The 'Diaspora' Diaspora," Ethnic and Racial Studies 28 (2005): 1-19.

40 David Garbin and Marie Godin, "'Saving the Congo': Transnational Social Fields and Politics of Home in the Congolese Diaspora," African and Black Diaspora: An International Journal 6, no. 2 (2013): 113-30.

41 Khalid Koser. "New African Diasporas: An Introduction," in New African Diasporas, ed. Khalid Koser, 1-16 (New York: Routledge, 2003).

42 Garbin and Godin, "Saving the Congo," 113.

43 CAYP's Congolese spokesperson, Sylvestre Mido, interview in London, 2014.
44 Public meeting, CAYP's Congolese spokesperson, Sylvestre Mido, November 2013

45 Ibid., 125.

46 Valeria Bello, "Virtual Belongings, Dual Identities and Cultural Discomforts: The Role of Mediaspaces and Technospaces in the Integration of Migrants," Crossings: Journal of Migration \& Culture 5, nos. 2-3 (2014): 213-29.

47 The Convention on the Prevention and Punishment of the Crime of Genocide was adopted by the United Nations General Assembly on 9 December 1948, as General Assembly Resolution 260. http://www.hrweb.org/legal/genocide html.

48 CAYP's Congolese spokesperson, Sylvestre Mido, interview in London, 2014.

49 The DRC has experienced protracted conflict for almost twenty years. This first Congo War is often referred to as the "War of Liberation" (1996-8) by most Congolese and is marked by the end of Zaïre, that is, Kabila renaming the country the Democratic Republic of Congo. Shortly afterwards, in 1998, a second war erupted between Kabila and Rwanda and Uganda (and to a lesser extent Burundi), who were asked by the new president of the DRC to leave the country. The second Congo war took place between 1998 and 2003 and has been called a "war of aggression." The third war is still ongoing between armed groups and civilians, with women and children being the most affected by the conflict. For more information, see Gerad Prunier, Africa's World War: Congo, the Rwandan Genocide, and the Making of a Continental Catastrophe (Oxford: Oxford University Press, 2009); Jason Stearns, Dancing in the Glory of Monsters: The Collapse of the Congo and the Great War of Africa (New York: PublicAffairs, 2012).

50 Congolese activist from CAYP, Geno-cost, 2013, London.

51 Victoria Bernal, "Diaspora, Digital Media, and DeathCounts: Eritreans and the Politics of Memorialisation," African Studies 72, no. 2 (2013): 246-64.

52 Directed by Kelvin Batumike, who is also known for the video clip "Happy: We Are from Goma," based on Pharrell Williams's song "Happy," YouTube, https://www.youtube. $\mathrm{com} /$ watch? $\mathrm{v}=$ fquin 2 jbPIg.

53 BBC, "Un Official Calls DR Congo 'Rape Capital of the World,"” April 28, 2010, http://news.bbc.co.uk/1/hi/8650112 .stm.

54 Lisa Shannon, A Thousand Sisters: My Journey into the Worst Place on Earth to Be a Woman (Berkeley: Seal, 2010).

55 See Richard Stallman's GNU manifesto published in 1985. He invented the notion of "copyleft" and started shipping software with a licence that permitted redistribution and modification under the condition that any derived material be subject to the same licensing terms.

56 Geno-cost commemoration day in London, 2 August 2013. 57 Ibid., 2014, and 2015.

58 Geno-cost Twitter account, 2 August, 2015.

59 July 2013. 
6o Simon Turner, "Staging the Rwandan Diaspora: The Politics of Performance," African Studies 72, no. 2 (2013): 265-84.

61 Victoria Bernal, "Diaspora, Digital Media, and Death Counts: Eritreans and the Politics of Memorialisation," African Studies 72, no. 2 (2013): 246-64.

62 Interview with JJ Bola in London, December 2014.

63 "Word on the Curb," YouTube, 2014, https://www.youtube. com/watch? $v=$ ouWqV31QqLo.

64 This refers to Speakers' Corner, in Hyde Park, London, the most famous location for free speech in the world. It symbolizes popular struggles in Britain for the right to vote, speak, and assemble See "Speakers' Corner," http://www. speakerscorner.net/.

65 Marta Bausells and Maeve Shearlaw, "Poets Speak Out for Refugees: 'No one leaves home, unless home is the mouth of a shark," Guardian, 15 September 2016, http://www.theguardian.com/books/2015/sep/16/ poets-speak-out-for-refugees-.

66 "Refuge" has been published in his latest poetry collection, WORD, by writer/poet JJ Bola, which was released on 18 June 2015 during Refugee Week.

67 Interview with JJ Bola in London, December 2014.

68 Stephen L. Keller, Uprooting and Social Change: The Role of Refugees in Development (Delhi: Manohor, 1975).

69 Liisa H. Malkki, "Refugees and Exile: From 'Refugee Studies' to the National Order of Things," Annual Review of Anthropology 24 (1995): 495-523.

70 Facebook exchanges, 2016.

71 JJ Bola, "tell them (they have names)," Word (Amazon e-book, 2015). See JJ Bola's other books: Elevate (Amazon e-book, 2014); and Daughter of the Sun (Amazon e-book,
2014). All JJ Bola's books can be purchased on Amazon or via his blog: www.jjbola.com.

72 The text was also shared on his Twitter account on 2 August 2015: "Some thoughts on humanity and why I no longer share images of dead bodies to raise awareness \# genocost). (African Renaissance @JJ Bola-https://twitter. com/Genocost).

73 Nira Yuval-Davis, "What Is 'Transversal Politics'?" soundings 12 (summer 1999): 94-8.

74 Bola, interview, 2014.

75 Bola, "Refuge."

76 Peggy Levitt and Lamba-Nieves Deepak, "Social Remittances Revisited," Journal of Ethnic and Migration Studies 37, no. 1 (2011): 1-22.

77 Yuval-Davis, "What Is 'Transversal Politics'?, 94.

78 "Global Summit to End Sexual Violence in Conflict," GOv.UK, https://www.gov.uk/government/topical-events/ sexual-violence-in-conflict.

79 Dr. Mukwege is a Congolese gynaecologist who founded and works at Panzi Hospital in Bukavu (South Kivu province, DRC), where he specializes in the treatment of women who have been raped in the protracted conflict situation. See "L'Hôpital de Panzi," http://www.panzihospital.org/.

80 JJ Bola's public statement at the Global Summit to End Sexual Violence in Conflict held on 10 June 2014 at Excel London during CAYP's workshop on conflict minerals not to be understood as a Congolese issue but as a global issue. See "Not All Messages about Rape Were Welcome at Hague and Jolie's Sexual Violence Summit," Congolese Action Youth Platform Blog, 14 June 2014, https://congoayuk.wordpress.com/tag/ global-summit-to-end-sexual-violence-in-conflict/. 